\title{
Influence of Apical Enlargement in Cleaning and Extrusion in Canals with Mild and Moderate Curvatures
}

\author{
Mauricia Ferreira de Almeida e BORGES ${ }^{1}$ \\ Carlos Eduardo Saraiva MIRANDA ${ }^{2}$ \\ Silvio Rocha Corrêa da SILVA ${ }^{3}$ \\ Melissa MARCHESAN ${ }^{4}$ \\ ${ }^{1}$ Brazilian Dental Association, Uberlândia, MG, Brazil \\ ${ }^{2}$ University of Ribeirão Preto, Ribeirão Preto, SP, Brazil \\ ${ }^{3}$ Araraquara Dental School, UNESP - Univ. Estadual Paulista, Araraquara, SP, Brazil \\ ${ }^{4}$ Nova Southeastern University, Fort Lauderdale, FL, USA
}

\begin{abstract}
Optical microscopy and morphometric analysis were used in this study to evaluate, in vitro, the cleaning of the apical region in root canals with mild or moderate curvatures subjected to biomechanical preparation with a rotary system, as well as to assess the amount of extruded material to the periapical area. Lateral incisors $(\mathrm{n}=32), 16$ with curvature angles smaller or equal to $10^{\circ}(\mathrm{GI})$ and 16 between $11^{\circ}$ and $25^{\circ}$ angles (GII) were submitted to Hero 642 rotary instrumentation with different surgical diameters: (A) 30.02 and (B) 45.02. Irrigation was performed at each change of instrument with $5 \mathrm{~mL}$ of ultrapure Milli-Q water and the extruded material through the apical foramen was collected. Root cross-sections were subjected to histological analysis by optical microscopy $(\times 40)$ and the images were evaluated morphometrically using the Image Tool software. Quantification of the extruded material was performed by weighing after liquid evaporation. ANOVA showed no statistically significant differences $(p>0.05)$ among the groups with respect to the procedures used to clean the apical region. Considering the amount of extruded material, the Tukey's HSD showed that canals with mild curvature prepared with the 45.02 surgical diameter showed significantly higher values $(\mathrm{p}<0.05)$ that those of the other groups, which were similar between themselves $(\mathrm{p}>0.05)$. In conclusion, the effect of cleaning the apical region did not differ in the groups, considering root curvature and the surgical diameter of instruments used for apical preparation. The amount of extruded material was greater in canals with mild curvature that were prepared with the 45.02 surgical instrument diameter.
\end{abstract}

Key Words: root canal cleaning, rotary instrumentation, apical extrusion.

\section{INTRODUCTION}

The mechanical action of endodontic instruments during biomechanical preparation combined with the physicochemical properties of irrigation solutions is aimed at cleaning and disinfecting toot canals and favor periapical repair (1). During this procedure, rests of excised dentin not removed by the irrigation/aspiration processes are kept inside the root canal, adhered to the walls and forming an amorphous structure called smear layer or, at the canal lumen in areas not reached by the endodontic instruments and/or irrigation solution forming debris that remain together with pulp remnants.

Scientific advancements have improved the development of new instruments, techniques and technologies, but complete removal of smear layer or debris has not yet been achieved (2,3). Anatomic variations are limiting factors in the biomechanical preparation of root canals, favoring the persistence of tissue remnants and bacterial debris in the isthmus, reentrances and ramifications of the canals $(3,4)$.

Cleaning of the apical canal third is obtained by correct shaping and irrigating procedures, but an accurate determination of the anatomic diameter and enlargement of the canal lumen are indispensable (5). According to Pasternak-Junior et al. (6), even greater enlargements could be done in curved canals due to the flexibility of nickel-titanium (NiTi) instruments,

Correspondence: Prof. Dr. Silvio Rocha Corrêa da Silva, Departamento de Odontologia Social, Faculdade de Odontologia de Araraquara, UNESP, Rua Humaitá, 1680, 14801-903 Araraquara, SP, Brasil. Tel: +55-16-3301-6355. e-mail: silvio@foar.unesp.br 
which allow increased final diameters with less risks of transportation. In addition, Fornari et al. (7) have shown that greater instrument diameters allow better fitting to the canal walls and produces more efficient cleaning. However, excised material composed of dentin chips, $\mathrm{vita} /$ necrotic pulp tissue fragments, microorganisms and irrigation solution might be forced beyond the apex in direction of the periapical region causing inflammatory reactions and post-instrumentation pain (8). The amount of material extrusion to the periapex varies according to the instrumentation and irrigation techniques, the apical patency and root curvature $(9,10)$.

Considering that extrusion of material to the periapical region during the biomechanical preparation of root canals may cause persistent inflammation and postoperative pain, it is relevant to reflect on the usefulness of increased instrument final diameter.

\section{MATERIAL AND METHODS}

Thirty-two human maxillary lateral incisors with completely formed roots, more than $19 \mathrm{~mm}$ of root length and no calcifications and internal resorptions were used.

Extruded material through the radicular foramen during biomechanical preparation was collected by a device constructed with $20 \mathrm{~mL}$ glass flasks with rubber covers and $0.5 \mathrm{~mL}$ Eppendorf tubes connected to the apical region of each tooth. Apical patency was gained by introducing a \#15 K-file (Dentsply-Maillefer, Ballaigues, Switzerland) into the root canal of each tooth until its tip was visible at the apical foramen. The working length (WL) was set $1 \mathrm{~mm}$ short of this measurement.

The roots were randomly assigned to two groups; $\mathrm{G} 1(\mathrm{n}=16)$ comprised roots with curvature angles equal or less $10^{\circ}$ (mild curvature) and $\mathrm{G} 2$ including roots with curvature angles ranging from $11^{\circ}$ to $25^{\circ}$ (moderate curvature). Each group was divided in two subgroups $(\mathrm{n}=8)$ according to the final instrumentation diameter to be used: 30.02 and 45.02 .

The root canals were prepared with rotary instruments (Hero 642; Micromega, Besançon, France) activated by an electric motor (Endo-Mate TC-NSK, Nakanishi Inc. Tokyo, Japan). In GI, half of the specimens was prepared with 30.06 instrument with 12 mm penetration, 30.04 instrument at $2 \mathrm{~mm}$ short of WL (16 mm penetration) and 30.02 instrument to the full WL. The other half of the specimens was prepared using the same sequence of instruments adding 35.02, 40.02 and 45.02 instruments to the full WL. In GII, half of the specimens was prepared with 25.06 instrument with 12 mm penetration, 25.04 instrument at $2 \mathrm{~mm}$ short of WL, 25.02 instrument to the full $\mathrm{WL}, 30.04$ instrument at 2 $\mathrm{mm}$ short of WL and 30.02 instrument to the full WL. The other half of the specimens was prepared using the same sequence of instruments adding 35.02, 40.02 and 45.02 instruments to the full WL. At each change of instrument, the canals were irrigated with $5 \mathrm{~mL}$ of ultrapure MiliQ water delivered by a plastic syringe (Ultradent, South Jordan, Utah, USA) with a 21-mm-long Navitip needle (Ultradent) with a rubber stop positioned at $12 \mathrm{~mm}$ from the tip. The prepared roots were stored in buffered 10\% formalin in individual containers.

The apical root third was sectioned with an scalpel were subjected to histological processing by the Leica TP 1010 automatic tissue processor (Leica Instruments GmbH, Nussloch, Germany). A Leica RM 2145 microtome (Leica Instruments) was used for the serial section of each specimen producing 6-mm-wide sections, which were stained with hematoxylin-eosin. The apical $1 \mathrm{~mm}$ was discarded. Ten sections of each apical third were selected for morphometric analysis with an optical microscope (Eclipse E 600, Nikon, Tokyo, Japan) fitted with a $4 \mathrm{X} / 0.13$ ocular lens, an amplifying objective $(10 \mathrm{X} / 25)$ and a final magnification of $\times 40$. Images were captured by the software Adobe Photoshop 5.1 (Adobe Systems Inc., San Jose, CA, USA) and analyzed with the Image Tool, version 3 software (UTHSCSA, San Antonio, TX, USA). The total cross-section area of the root canals and the area containing debris were determined by a measuring device. Percentages of the cross-section area occupied by debris were calculated from the two measurements. To determine extrusion, the coverless (sectioned) Eppendorf tubes were dehumidified for $12 \mathrm{~h}$ in an calcium carbonate atmosphere and weighed in a precision balance $\left(10^{-4}\right.$ OHAUS Analytic Standard, Model AS 200 MFD; OHAUS Corporation Forham Dark, NJ, USA). The final weight was an average of five measurements.

Data were analyzed statistically by ANOVA and HSD Tukey test at 5\% significance level (SPSS software, version 17.0, SPSS Inc., Chicago, IL, USA).

\section{RESULTS}

Means and standard deviation of remaining debris in the apical third of different curvature root canals (percent values) and the amount of material extruded after different procedures are shown in Table 1. 
There were no statistically significant differences between areas (\%) occupied by debris either in root canals with mild and moderate curvatures curved roots or in those prepared with instruments of different diameters. Values of $\mathrm{p}$ were 0.90 for differences between mild and moderately curved roots, 0.31 for different instrument diameters (30.02 and 45.02) and 0.99 for the interaction curvature versus surgical diameters.

As to the weights of extruded material, the values for different surgical diameters were not statistically different $(p=0.063)$. However, mildly and moderately curved root canals showed significant differences in the amount of extruded material $(\mathrm{p}=0.036)$ as well as in the interactions between different curvatures and surgical instruments, 30.03 and 45.02 diameters $(\mathrm{p}=0.017)$.

Root canals with mild curvature prepared with the 45.02 instrument to the full WL showed the highest values for extruded material to the periapical region $(0.87 \pm 0.22)$. This result was significantly different $(p<0.05)$ from the other combinations, which, in turn, were statistically similar among themselves $(p>0.05)$.

Figures 1 and 2 show representative photomicrographs of representative cross-sections at the apical level from mildly and moderately curved roots, respectively, after preparation with instruments of different diameters. In both types of root canals (mild and moderate curvatures), preparation with 35.02 diameter did not touch all canal walls (Figs. 1 and 2A,B) while the use of the 45.02 diameter increased canal wall cleaning, although it is still possible to see pre-dentin in several sections.

Table 1. Means and standard deviation of remaining debris in the apical third of different curvature root canals and material extrusion after different procedures.

\begin{tabular}{lcc}
\hline $\begin{array}{l}\text { Final instrument } \\
\text { diameter }\end{array}$ & Debris (\%) & Extrusion (mg) \\
\hline Mild curvature & $3.02 \pm 2.88 \mathrm{a}$ & $0.66 \pm 0.07 \S$ \\
30.02 & $2.14 \pm 2.07 \mathrm{a}$ & $0.87 \pm 0.22 \Delta$ \\
45.02 & & \\
Moderate curvature & $2.92 \pm 2.74 \mathrm{a}$ & $0.68 \pm 0.11 \S$ \\
30.02 & $2.09 \pm 1.49 \mathrm{a}$ & $0.65 \pm 0.09 \S$ \\
45.02 &
\end{tabular}

Different letters and different symbols indicate statistically significant differences for debris and material extrusion, respectively. HSD Tukey test $\mathrm{p}<0.05$.

\section{DISCUSSION}

Literature reports indicate that biomechanical preparation in curved root canals should be performed by Ni-Ti rotary instruments highly tapered and with a minimum final apical diameter (ISO size 20, 25 or 30 ), which produce compacted filling material and less extrusion (11). Khademi et al. (12) considered that removal of dentin from the apical region is not necessary when the coronal portion is adequately prepared, and that a size 30 instrument is able to produce the smallest enlargement necessary for adequate penetration of irrigants into the apical third.

Fornari et al. (7) reported that better cleaning is obtained in severely curved roots when final instruments of greater diameter are used, but this greater enlargement and apical patency may result in material extrusion to the periapical region causing persistent inflammation and postoperative pain (8). Thus, it is important to reach a balance between using final instruments with greater diameter of during root canal shaping and the amount of material extruded to the periapex.

The influence of final instrument diameter in apical cleaning in curved root canals was assessed in this study by using diameters 30.02 and 45.02. Diameter 30 was selected based on the reports of Kademi et al. (12) mentioned above. The choice for diameter 45 was based on the conclusions of Pasternak-Junior et al. (6) that $\mathrm{Ni}-\mathrm{Ti}$ instruments are more indicated to increase canal enlargement even in roots with accentuated curvatures, as they can be maintained centered in the canal. Instrument manufacturers suggest that moderately curved canals should be prepared with instruments up to size 30 .

In this study, apical cleaning was assessed by the morphometric analysis of root cross-sections to determine the percent canal areas occupied by debris, as reported elsewhere $(7,13,14)$. The morphometric analysis was performed with Image Tool software, an image-analysis software that provides good acuity and accurate measurements of delineated areas $(7,14)$.

Collection of excised material was performed by a reproducible, widely accepted method using a custommade device, which was designed to collect all material extruded though the apex (10). After evaporation of the irrigation solution and drying, the material was weighed.

Criteria for root selection in this study were the curvature angle, measured by orthoradial radiography using Schneider's method, and the parameters described by Pruett et al. (16). According to Pruett et al. (16), two 
canals may have the same curvature but different radius. The smaller the radius, the more abrupt the curvature, negatively influencing transport and making it difficult to touch root canal walls with the instrument. Thus, the root canals chosen in this study had mild $\left(\leq 10^{\circ}\right)$ and moderate curvatures $\left(11\right.$ to $25^{\circ}$ ).

The results of the present study suggest that removal of debris from the apical third does not depend on the root curvature or the final instrument diameter used in the biomechanical preparation, although Fornari et al. (7) claimed that instruments with greater diameters allow a better contact with canal walls and, thus, more effective cleaning.

The manufacturer's instructions and the findings of Kademi et al. (13), who reported that root canals with moderate curvatures should be prepared with instruments up to size 30 , which is the smallest enlargement necessary for adequate penetration of chemical solutions into the apical third. However, in the present study, the qualitative analysis of histological sections showed that canals shaped with size 30 instrument showed untouched dentin walls. This is in contrast with the results obtained with the size 45 instrument, which provided better contact with canal walls regardless of root curvature, corroborating the findings of Fornari et al. (7).

Ibelli et al. (17) demonstrated that clinical determination of the root anatomic diameters varied from size 30 to 45 after cervical preparation, implying inadequate action of instrument 30 in the apical region. Therefore, it seems more reasonable to establish final instrument diameters based on the anatomic diameter after cervical preparation instead, as the manufacturer
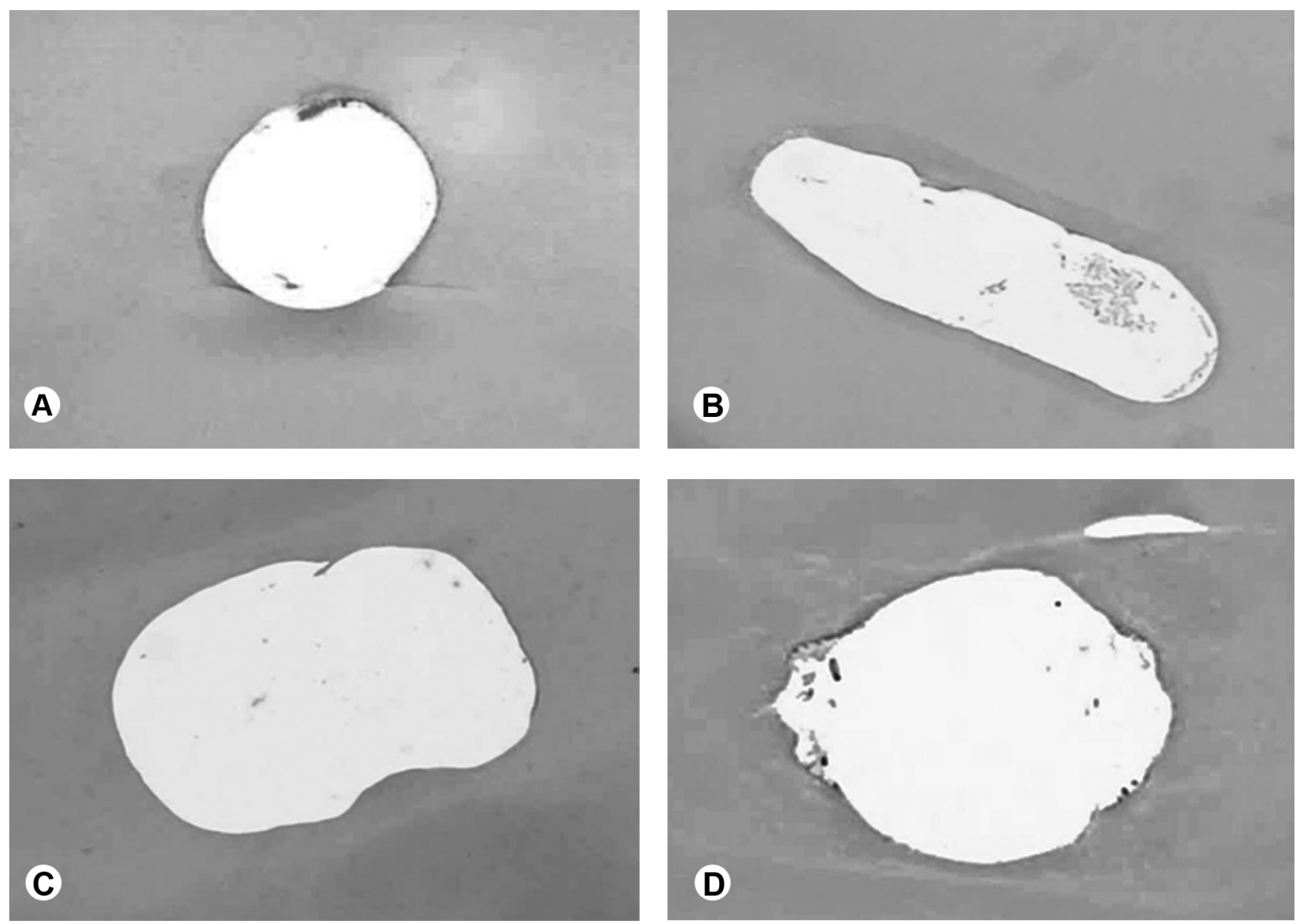

Figure 1. Photomicrographs of representative cross-sections at the apical level in mildly curved roots (original magnification $\times 40$ ) A. Cross-section of a root canal with mild curvature prepared with a final instrument diameter 30.02 , showing pre-dentin. B. Cross-section of a root canal with mild curvature with elliptical configuration, prepared as in A, showing debris in the canal lumen. C. Cross-section of a root canal with mild curvature prepared with final instrument diameter 45.02, showing debris in the canal lumen. D. Cross-section of a root canal with mild curvature prepared as in $\mathrm{C}$ showing greater wall touching by instrumentation. 
suggests, on the root curvature, as larger canal enlargements even in accentuated root curvatures are possible due to the flexibility of NiTi instruments (6).

In the present study, extrusion of material to the periapex was shown to be significantly different in canals with mild curvatures prepared with instrument 45 in comparison to all other combinations. Previous studies have shown that material extrusion may be related to root canal anatomy and instrumentation technique (10), although emphasizing that no technique is free from the risk of pushing material to the periapical region $(19,20)$.

The greater extrusion values shown in the canals with mild curvature could be explained by the greater alignment of foramen and canal direction, although that rotary instrumentation tends to promote material
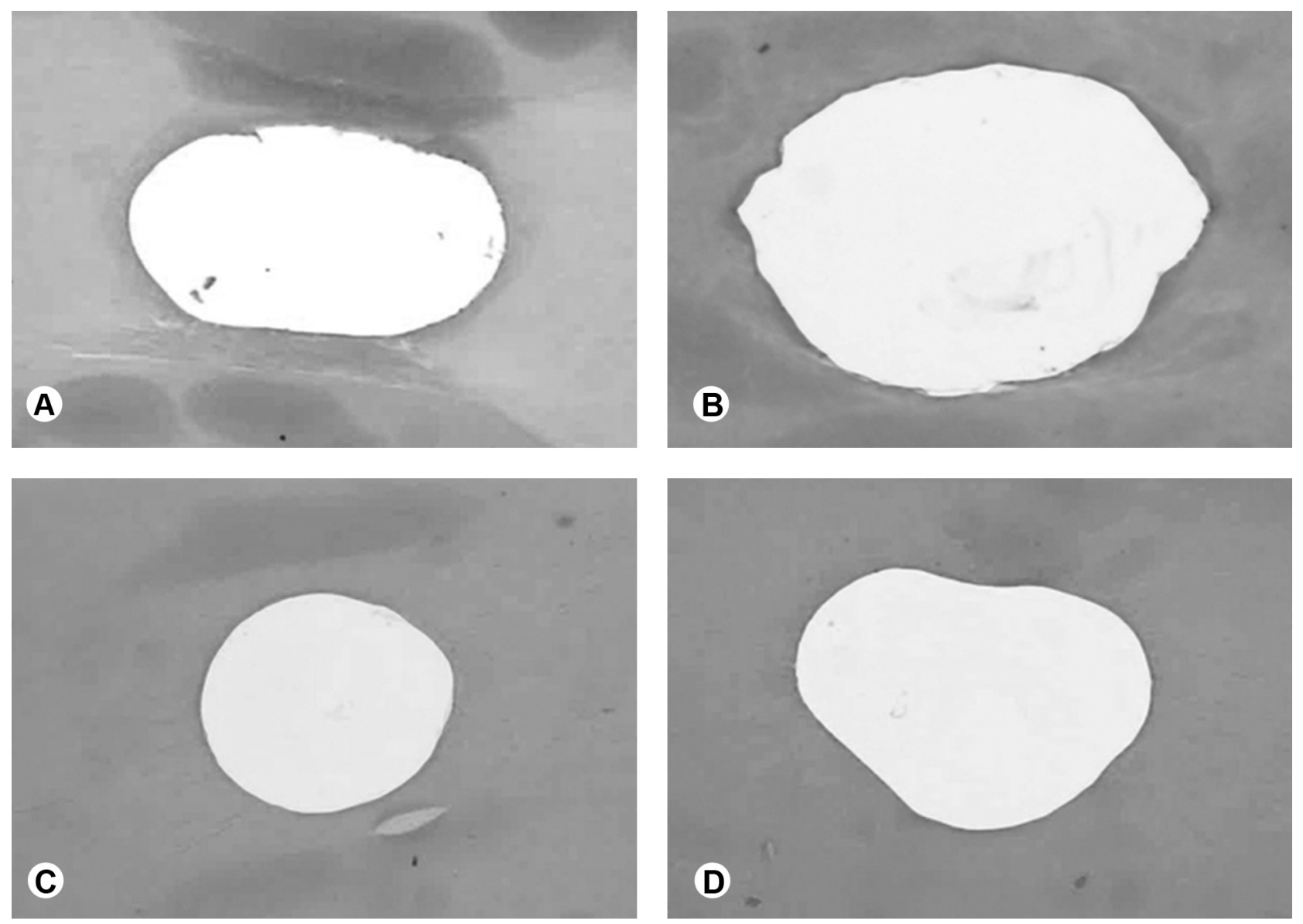

Figure 2. Photomicrographs of representative cross-sections at the apical level in moderately curved roots (original magnification $\times 40$ ). A. Cross-section of a root canal with moderate curvature prepared with a final instrument diameter, 30.02, showing debris in the canal lumen and pre-dentin. B. Cross-section of a root canal with moderate curvature, prepared as in A, showing circular configuration and few wall touching by instrumentation. C. Cross-section of a root canal with moderate curvature prepared with a final instrument diameter 45.02, showing a circular configuration and debris in the canal lumen. D. Cross-section of a root canal with moderate curvature, prepared as in $\mathrm{C}$, showing improved dentin touching by instrumentation. reflux (21). The same anatomic structure may also be involved in the higher pressure of irrigating solutions in comparison to moderate or accentuated root curvatures, thus increasing extrusion. According to Hinrichs et al. (22) and Ferraz et al. (21), the amount of extruded material is related to the volume of the irrigating solution.

The findings of this study confirmed those of Leonardi et al. (23), who found no significant differences in apical extrusion among canals with different curvatures prepared with size 30 instrument. The significant apical extrusion in canals with mild curvatures prepared with size 45 instrument is confirmed by previous reports $(23,24)$. Lambrianidis et al. (25) observed greater amount of extrusion when the apical constriction was kept intact previously to enlargement. 
Concern with the biomechanical preparation is still a reality in endodontic practice. Further studies are needed to verify apical cleaning and extruded material in root canals prepared with NiTi instruments, by increasing the final instrument diameter after determination of the anatomic diameter.

\section{RESUMO}

Este estudo avaliou, in vitro, por meio de microscopia óptica e morfometria, a limpeza da região apical em canais radiculares com curvatura leve e moderada submetidos ao preparo biomecânico com sistema rotatório, bem como avaliou a quantidade de material extruído para a área apical. Incisivos laterais $(\mathrm{n}=32)$, sendo 16 com ângulo de curvatura igual ou inferior a $10^{\circ}$ (GI) e 16 entre $11^{\circ}$ e $25^{\circ}(\mathrm{GII})$, foram submetidos à instrumentação rotatória com o sistema Hero 642 com diferentes diâmetros cirúrgicos: (A) 30,02 e (B) 45,02. A irrigação, a cada troca de instrumento, foi realizada com água ultra-pura de Milli Q $(5 \mathrm{~mL})$, e o material extruído através do forame apical foi coletado. As raízes foram submetidas a análise histológica sob microscopia óptica $(40 \times)$ e as imagens foram submetidas à análise morfométrica utilizando o software Image Tool. A quantificação do material extruído foi realizada por pesagem, após a evaporação do líquido. A análise de variância não mostrou diferença estatística significante em relação à limpeza da região apical nos diferentes grupos testados $(p>0,05)$. Considerando a quantidade de material extruído, o teste de T6ukey mostrou que os canais com curvatura leve preparados com o diâmetro cirúrgico 45,02 apresentaram os maiores valores, sendo estatisticamente diferente dos demais grupos $(\mathrm{p}<0,05)$ que foram semelhantes entre si $(p>0,05)$. Pode-se concluir que a limpeza da região apical não diferiu entre os diferentes grupos, considerando a curvatura radicular e o diâmetro cirúrgico. A quantidade de material extruído foi maior nos canais preparados com curvatura leve que foram preparados com diâmetro cirúrgico 45,02.

\section{REFERENCES}

1. Siqueira-Júnior JF. Microbial causes of endodontic flare-ups. Int Endod J 2003;36:453-463.

2. Barbizam JV, Fariniuk LF, Marchesan MA, Pecora, JD, Sousa-Neto, MD. Effectiveness of manual and rotary instrumentation techniques for cleaning flattened root canals. J Endod 2002;28:365-366.

3. Fariniuk LF, Baratto-Filho F, Cruz-Filho AM, Sousa-Neto MD. Histologic analysis of the cleaning capacity of mechanical endodontic instruments activated by the ENDOflash system. J Endod 2003;29:651-653.

4. Baratto-Filho F, Leonardi DP, Zielak JC, Vanni JR, Sayão-Maia SMA, Sousa-Neto MD. Influence of ProTaper finishing files and sodium hypochlorite on cleaning and shaping of mandibular central incisors - A histological analysis. J. Appl Oral Sci 2009;17:229-233.

5. Wu MK, Barkis D, Roris A, Wesselink PR. Does the first file to bind correspond to the diameter of the canal in the apical region? Int Endod J 2002;35:264-267.

6. Pasternak-Junior B, Sousa-Neto MD, Silva RG. Canal transportation and centring ability of RaCe rotary instruments. Intern Endod $\mathrm{J}$ 2009;42:499-506.

7. Fornari VJ, Silva-Souza YTC, Vanni JR, Pécora DJ, Versiani MA, Souza-Neto MD. Histological evaluation of the effetiveness of increased apical enlargement for cleaning the apical third of curved canals. Int Endod J 2010;43:988-994.

8. Zarrabi MH, Bidar M, Jafarzadeh $\mathrm{H}$. An in vitro comparative study of apically extruded debris resulting from conventional and three rotary (Profile, Race, FlexMaster) instrumentation techniques. J Oral Science 2006;48:85-88.

9. Leonard LE, Atlas DM, Raiden G. Apical extrusion of debris by manual and mechanical instrumentation. Braz Dent J 2007;18:1619.

10. Vansan LP, Pécora JD, Costa WF, Silva RG, Savioli RN. Comparative in vitro study of apically extruded material after four different root canal Instrumentation techniques. Braz Dent J 1997;8:79-83.

11. Young GR, Parashos P, Messer HH. The principles of techniques for cleaning root canals. Aust Dent J 2007;52:52-63.

12. Khademi A, Yazdizadeh M, Feizianfard M. Determination of the minimum instrumentation size for penetration of irrigants to the apical third of root canal systems. J Endod 2006;32:417-420.

13. Marchesan MA, Arruda MP, Silva-Sousa YTC, Saquy PC, Pecora JD, Sousa-Neto MD. Morphometrical analysis of cleaning capacity using nickel-titanium rotary instrumentation associated with irrigating solutions in mesio-distal flattened root canals. J Appl Oral Sci 2003;11:55-59.

14. Nadalin MR, Perez DEC, Vansan LP, Paschoalato C, SousaNeto MD, Saquy PC. Effectiveness of different final irrigation protocols in removing debris in flattened root canals. Braz Dent $\mathrm{J}$ 2009;20:211-214.

15. Schneider SW. A comparison of canal preparations in straight and curved root canals. Oral Surg Oral Med Oral Pathol 1971;32:271275.

16. Pruett JP, Clement DJ, Carnes DL. Cyclic Fatigue of NickelTitanium Endodontic Instruments. J Endod 1997;23:77-85.

17. Ibelli GS, Barroso JM, Capelli A, Spanó JCE, Pécora JD. Influence of cervical preflaring on apical file size determination in maxillary lateral incisors. Braz Dent J 2007;18:102-106.

18. Vanni JR, Santos R, Limongi O, Guerisoli DMZ, Capelli A, Pécora $\mathrm{J} D$. Influence of cervical preflaring on determination of apical file size in maxillary molars: SEM analysis. Braz Dent J 2005;16:181186.

19. Kustarci A, Akpinar KE, Er K. Apical extrusion of intracanal debris and irrigant following use of various instrumentation techniques. Oral Surg Oral Med Oral Pathol Oral Radiol Endod 2008;105:257262.

20. Araquam, KR, Britto MLB, Nabeshima CK. Evaluation of apical extrusion of debris during ultrasonic versus rotary instrumentation. Rev Odonto Ciênc 2009;24:32-35.

21. Ferraz CC, Gomes NV, Gomes BP, Zaia AA, Teixeira FB, SouzaFilho FJ. Apical extrusion of debris and irrigants using two hand and three engine-driven instrumentation techniques. Int Endod J 2001;34:354-358.

22. Hinrichs RE, Walker WA III, Schindler WG. A comparison of amounts of apically extruded debris using handpiece-driven nickeltitanium instrument systems. J Endod 1998;24:102-106.

23. Tinaz AC, Alacam T, Uzun O, Maden M, Kayaoglu G. The effect of disruption of apical constriction on periapical extrusion. J Endod 2005;31:553-555.

24. Mitchell PR, Yang SE, Baumgartner JC. Comparison of apical extrusion of $\mathrm{NaOCl}$ using the EndoVac or needle irrigation of root canals. J Endod 2010;36:338-341.

25. Lambrianidis T, Tosounidou E, Tzoanopoulou M. The effect of maintaining apical patency on periapical extrusion. J Endod 2001;27:606-609. 